\title{
Normalization of Monetary Policy After Global Crisis: What is Normalization?
}

\section{N. Hande SEVGi ${ }^{1}$}

\section{Küresel Kriz Sonrası Para Politikasının Normalleşmesi: Normalleşme Nedir?}

\begin{tabular}{l} 
ARTICLE INFO \\
\hline Article History: \\
Date Submitted: 14.07 .2017 \\
Date Accepted: 15.08 .2017 \\
\hline JEL Classification: \\
E40, \\
E52, \\
E58, \\
E61. \\
Keywords: \\
Monetary Policy, \\
Central Bank, \\
Unconventional Monetary \\
Tools.
\end{tabular}

\author{
ABSTRACT \\ Global financial crisis was not only created a chaos but also changed the \\ contemporary monetary policy. The global economy faced with a shift on policy \\ tools because by starting the liquidity trap that American economy faced forced \\ the authorities to find new strategies. Policy makers have started to consider \\ financial stability with price stability and to reshape monetary policy they created \\ new policy tools.
}

The descried tools for new exit ways of powerful central banks especially Fed, helped to overcome the global crisis while bringing new issues. Under the circumstances Fed started a normalization process for monetary policy. Due to the gravity of Fed, other central banks had to adopt the current stream. In this conjuncture Central Bank of the Republic of Turkey has changed the policy tools correspondingly. The purpose of this paper is to evaluate the change in the monetary policy path of Fed and ECB with the behavioral pattern of Central Bank of the Republic of Turkey with "New Normalization" concept.

\footnotetext{
${ }^{1}$ Res. Asist., Gazi University, Department of Economics, handesevgi@gazi.edu.tr
} 


\section{Özet}

Küresel finansal kriz, yalnızca bir kaos yaratmakla kalmadı, aynı zamanda modern para politikasını da değiştirdi. Küresel ekonomi, para politikası araçlarında bir değişimle karşı karşıya kaldı; çünkü likidite tuzağındaki Amerikan ekonomisi karşısında karar alıcıları yeni çözüm yolları arayışına girmeye zorladı. $\mathrm{Bu}$ durum karşısında politika yapıcılar fiyat istikrarının yanında finansal istikrarı da gözeterek para politikasını yeniden şekillendirecekleri yeni araçlar ortaya koydular.

Başta Fed olmak üzere güçlü merkez bankalarının yeni çıkış yolları için ürettikleri araçlar, küresel krizin üstesinden gelmeye yardımcı olurken beraberinde yeni sorunlar da getirdi. Bu durumda da Fed para politikasında normalleşmeye gitme kararı aldı. Fed'in önemi dolayısıyla diğer merkez bankaları da bu akıma adapte olmak zorunda kaldı. Bu konjonktüre bağlı olarak Türkiye Cumhuriyet Merkez Bankası da politika araçlarında değişikliğe gitti. Bu çalışmanın amacı, Fed'in ve Avrupa Merkez Bankası'nın izlediği para politikasındaki değişiklikleri TCMB’nin davranış kalıbındaki değişiklikle birlikte "Yeni Normalleşme" kavramı ile birlikte değerlendirmektir.

Anahtar Kelimeler: Para Politikası, Merkez Bankası, Geleneksel Olmayan Parasal Araçlar.

\section{Introduction}

In year 2007 the detoriation on the housing market in United states could not be kept under control and led the economy to a very deep distress. With the collapse of Lehman Brothers the crisis deepened and spread almost all over the world. The material impacts of the crisis have maintained until the end of 2009. (CBRT, Annual Report, 2009: 25)

\footnotetext{
"Ever since the onset of the Crisis in 2008, the global economy has been repeatedly flirting with a descent into an even more damaging deflationary depression. Policymakers have averted this only by a combination of luck, judgement, and experimentation.,"2
}

\footnotetext{
${ }^{2}$ Cliffe, M. (2016). The New Normal That Never Was. Voxeu.
} 
The global financial crisis push the economy into a very significant bottleneck. In most countries central banks responded by cutting short term interest rates. But in some countries monetary authorities faced zero lower bound constraint. The global financial crisis that began in 2007 had profound effects on the U.S. economy and other economies around the world. Due to the crisis U.S. short-term interest rates were progressed nearly zero and let the economy to fall into liquidity trap and caused the expansionary monetary policies dysfunctional. As a consequence the outlook on monetary policy has changed and lead the monetaey authorities to seek new policies.

Due to the size of the US economy and close financial link with the rest of the world it has irrefutable influence on other economies. Fed is a very important agent of monetary policy determination process for almost all central banks.

Global financial crisis was not only created a chaos but also changed the contemporary monetary policy. Price stability has long been divine objective of monetary policy. But the global financial crisis revealed that the contemporary macroeconomy was not enough to obtain a sustainable economy. Policy makers sadly perceived that focusing on price stability, might cause the authorities to be blind when financial stability is under threat. After the crisis it became obvious that price stability could not be the only aim anymore. In other words, "The global financial crisis has highlighted the importance of monitoring and assessing the overall financial conditions for the conduct of sound macroeconomic policy."3

Policy makers have started to consider financial stability and in order to reshape monetary policy they created new policy tools. When the conventional policy tools became insufficient, the monetary and financial authorities has necessitated the use of broad range of instruments, which are called unconventional policy tools.

\section{Fed Actions}

"The Federal Open Market Committee (FOMC) reduced short-term interest rates to nearly zero and held them at that exceptionally low level for seven

\footnotetext{
${ }^{3}$ Başçı, E. \& Kara, H. (2011). Financial Stability and Monetary Policy. CBRT Working Paper, No: 11/08.
} 
years. Fed started a new programme called Quantitative Easing since The American economy was in liquidity trap. The FOMC also undertook largescale open-market purchases of longer-term U.S. Treasury securities and mortgage-backed securities (MBS) to put downward pressure on longer-term interest rates. The term 'normalization of monetary policy' refers to plans for returning both short-term interest rates and the Federal Reserve's securities holdings to more normal levels.",

In response to the global financial crisis and the slow recovery of Great Recession, the Fed engaged in some unconventional monetary policies. Fed had not so many choice but to opt massive liquidity injections. These policies of Fed, namely forward guidance and quantitative easing were put into place in the depths of crisis. By quantitative easing Fed could purchase monetary instruments and financial assets from commercial banks in order to stimulate the economy, and increase the monetary base, since the mainstream policies were underwhelmed.

The first quantitative easing was realized between December, 2008 and July, 2010 with 800 billion US Dollars purchase. This was not enough to stimulate demand. A new qe programme was released on October, 2010 with a lower purchase of longer term papers. On September, 2011 Fed made an operation twist of 400 billion US Dollars and on September, 2012 supported this with the third quantitative easing and continued with fourth on January, 2013. With this last quantitative easing, Fed declared that the monetary expansion will end when the unemployment rate falls under $6.5 \%$ or when inflation rate reaches $2.5 \%$. In year 2014 Fed ended this expansionary policy process.

Unfortunately the strategies of Fed that helped stop the crisis could not fixed the real side of the economy and caused massive balance sheet expansion. In comparison to the beginning periods of the financial crisis, Fed's balance sheet showed a dramatic change. Due to the quantitative easing programmes the financial assets of Fed has turned around five times in comparison with pre crisis period. As a result, balance sheet to GDP ratio has been increased

\footnotetext{
${ }^{4}$ https://www.federalreserve.gov/faqs/what-does-federal-reserve-mean-when-it-talks-about-normalization-ofmonetary-policy.htm
} 
to $23 \%$ from 5\% precrisis level. In 2017 Fed declared that they will start balance sheet reduction programme.

Table.1: Fed's Balance Sheet (Billion US Dollars)

\begin{tabular}{|c|c|c|c|c|c|c|c|}
\hline \multicolumn{4}{|l|}{ August 2007} & \multicolumn{4}{|l|}{ September 2017} \\
\hline \multicolumn{2}{|l|}{ Assets } & \multicolumn{2}{|l|}{ Liabilities } & \multicolumn{2}{|l|}{ Assets } & \multicolumn{2}{|l|}{ Liabilities } \\
\hline Financial Assets & 791 & Fed Reserve & 777 & Financial Assets & 4248 & Fed Reserve & 1580 \\
\hline $\begin{array}{l}\text { Treasury Securities } \\
\text { (US) }\end{array}$ & 791 & Bank Reserves & 17 & $\begin{array}{l}\text { Treasury } \\
\text { Securities (US) }\end{array}$ & 2465 & Bank Reserves & 2293 \\
\hline $\begin{array}{l}\text { Federal Agency } \\
\text { Securities }\end{array}$ & 0 & $\begin{array}{l}\text { Reverse } \\
\text { Repurchase } \\
\text { Agreements }\end{array}$ & 0 & $\begin{array}{l}\text { Federal Agency } \\
\text { Securities }\end{array}$ & 7 & $\begin{array}{l}\text { Reverse } \\
\text { Repurchase } \\
\text { Agreements }\end{array}$ & 373 \\
\hline $\begin{array}{l}\text { Mortgage } \\
\text { Securities }\end{array}$ & 0 & Other Liabilities & 43 & $\begin{array}{l}\text { Mortgage } \\
\text { Securities }\end{array}$ & 1776 & Other Liabilities & 225 \\
\hline $\begin{array}{l}\text { Repurchase } \\
\text { Agreements }\end{array}$ & 25 & Total Capital & 34 & $\begin{array}{l}\text { Repurchase } \\
\text { Agreements }\end{array}$ & 0 & Total Capital & 40 \\
\hline Other Assets & 55 & & - & Other Assets & 263 & & \\
\hline Total & 871 & Total & 871 & Total & 4511 & Total & 4511 \\
\hline
\end{tabular}

Source: Fed.

Fed has started normalization of monetary policy strategy to return both short-term interest rates and the securities holdings to more normal levels. In September 2014, when authorities explained Fed's plans they declared few key points. They mentioned that the normalization of balance sheet could only be held by the normalization of federal funds. If the economy goes on a stable line the normalization condition could be satisfied. In this phase Treasury holdings and agency securities will help the balance sheet tighten. This process will be predictable and the FOMC will continue to use Federal Fund Rate on determination of the policy stance. Once the normalization starts it will be expected that the process will continue as it is planned unless a deterioration happened in economic outlook. (Powell, 2017)

Why did Fed started to reduce the balance sheet?

"While the total size of central bank balance sheets reached new heights, the trajectories followed by individual central banks were quite diverse. All this occurred as the global recovery gained traction, financial market conditions tightened somewhat, and inflation picked up in advanced economies while edging down on average in emerging market economies. "5

\footnotetext{
${ }^{5}$ Bank of International Settlements BIS, 87th Annual Report.
} 
First of all, central banks do not wish to hold bonds exceeding the sufficient amount to conduct monetary policy. Central bank realizes bond purchases for financing public deficit. But this is not a sustainable situation. Moreover, this policy causes high rates of inflation, which contradicts the price stability target. Another aspect of growing balance sheet volume is that the excessive size causes/induces problems on monetary policy implemmentations. Bond purchases leads high liquidity which causes Fed loose control on short term interest rates. Even if Fed intends to raise the interest rate, the (excess) liquidity will hold short term interest rates at zero lower bound and moreover may pull it down. At this point Fed changed monetary policy implementations and started to pay interest to reserve requirements and started to apply reverse repurchase agreement for financial organizations.

\section{Euro Zone Behaviour}

The behavior of banking credit and bank's reserves was different in Euro Zone. First of all Euro Zone had an additional crisis trigger after the collapse of Lehman Brothers that is the announcement of Greek Prime Minister indicating Greece's budget deficit will be more than double.

\section{"Although it was affected by both events, the impact of the Euro Zone crisis was stronger in Europe than Lehman's collapse. The qualitative behaviour of banks' credit following widely observed crisis triggers is similar in the Eurozone and in the US, but the behaviour of their reserves is quite different." 6}

ECB implied liquidity injections programmes. In October 2008, fixed-rate, fullallotment (FRFA) liquidity provision introduced. The second programme was the covered bonds purchasing plan (CBPP) which introduced in June 2009 with 60 billion worth of eurodenominated covered bonds purchase over a period of one year. As the third liquidity injection Securities Market Programme (SMP) was out into practice in May 2010 with total volume of $€ 210$ billion. In December 2011 ECB launched Long-Term Refinancing Operation (LTRO) and relaunch in February 2012 totally involving three-year loans to banks against appropriate

\footnotetext{
${ }^{6}$ Cukierman, A. (2016). Global Crisis in the US vs the Eurozone: Banks and monetary policy. Voxeu.
} 
collateral about $€ 1$ trillion. As the last programme Outright Monetary Transactions (OMT) was announced in August 2012. (Cukierman, 2016)

The Euro Zone's ability to prevent major procyclical shrink by the next shock depends on whether the right policy choices are made during the ongoing recovery or not. (Thomsen, 2017). By starting the second half of 2017, the recovery in European Economy became evident. The reflation together with the political stability "normalization process has brought into question by ECB. Here things are a little bit different. First of all interest rates are negative and second, unlike Fed, ECB was not implementing open-ended puchases of bonds. This means as opposite to Fed, ECB had time constraint and had to convince the market about the duration of current programme.

\section{What Did Central Bank of the Republic of Turkey Do?}

Global financial crisis spread over the rest of the world. Turkey also had to reshape it's monetary policy in this conjuncture. Central Bank of Republic of Turkey (CBRT) developed new policy tools for the new policy mix. In this context, CBRT left conventional one target one tool mentality and started to use a variety of unconventional policy tools for providing both financial stability and price stability. By starting 2010, CBRT shifted the policy framework that supervises financial stability from the macro perspective and financial stability and price stability became two complementary aims and moreover financial stability stands in the objective function of central bank.

With it's exit strategy announces in April 14, 2010 CBRT changed the definition of the policy rate to one-week repo rate. CBRT started to use a new tool called asymmetric interest rate corridor. The interest rate corridor which defined as the area between overnight lending and borrowing rates that currently used in conventional inflation targeting have changed in meaning. With the new policy mix interest rate corridor can be defined asymmetrically around the policy rate. It is used actively rather being passive. (CBRT, 2013: 4,5) By his new structure interest rate corridor became a tool which has control over short term capital flows and credit growth. (CBRT, 2012: 30) 
The thing here is, by the new definition and structure of interest rate corridor degree of predictability is used as a policy tool and CBRT can affect the predictability be using the asymmetric interest rate corridor. For instance at times of low global risk apetite and weak capital flows CBRT has a power to increase predictability or vice versa, so that CBRT can control the volatility of capital flows. (CBRT, Bulletin 27: 3)

In the concept of new policy mix, reserve requirements are used as a monetary policy tool and a new term has introduces: Reserve option mechanism (ROM). With this new tool CBRT aimed to take high volatility of capital flows under control via letting to hold reserves as gold or forein currency. (CBRT, 2013: 5; CBRT, 2015: 61).

ROM basically allows banks to keep a certain ratio of their Turkish lira reserve requirements in foreign exchange and/or gold. There are two main terms in this mechanism. One is reserve option ratio (ROR). ROR determines the fraction of TL required reserves that can be held in foreign exchange or gold. The other term is reserve option coefficient (ROC). ROC determines the amount of foreign exchange or gold that can be held per unit of Turkish lira. For example, if the ROC is told to be 2, then banks must hold 2 liras worth of foreign exchange or gold per $1 \mathrm{TL}$ reserve requirement if they want to take the advantages of ROM. (CBRT, 2012: 30; Alper, Kara and Yörükoğlu, 2013)

ROR provides an option to banks about diversifying their reserve requirements. CBRT defines a ROC for every ROR and can differentiate ROR by additional tranches and ROC also does not have to be constant across all tranches. Because it is assumed that increasing ROC depending upon ROR will be more effective, CBRT prefers an implementation depending on the usage of ROC. Since ROC will increase for every single trash added, as the ratio of holding foreign exchange or gold as a part of required TL reserves will face with a higher ROC. (Alper and Kara, 2012: 2)

The facilities of ROM effects banks via cost and liquidity channels. The mechanism provides banks flexibility about liquidity management. So that banks could hold reserves less costly. The opportunity to accumulate foreign exchange will allow to mitigate the adverse effects of short-term capital inflows on exchange rates and loans. ROM may also limit the 
effects of short-term capital flows on lending, thus reduce the sensitivity of lending to capital movements. In addition, it will reduce the need for short-term currency swap transactions, which the CBRT is using to meet its liquidity needs, and will lead to a reduction in incoming capital flows. With the help of ROC, CBRT will be able to influence the cost of funding sources by changing the demand for banks' other funding sources. (Küçüksaraç and Özel, 2012: 2-5)

Global crisis and shift from conventional monetary policies to conventionals influenced CBRT and diversification of tools has been realized. Inevitably the downward tendency of global risks and the normalization process of Fed had an impact on Turkey's monetary policy and on August 2015 CBRT announced a roadmap followed during the normalization of global monetary policies.

CBRT defined the framework of turkish lira liquidity management and simplification steps, foreign exchange liquidity measures and measures to support financial stability. According to this, before normalization, The total funding facility currently provided to the market maker banks will be added to the weekly maturity amount repo auction limit accounts so that the market makers will not change the cost of funding from the CBRT. Thus the interest rate on borrowing facilities granted to the market maker banks will be removed. During the normalization interest rate corridor will be more symmetric around one-week repo interest rate and the width of the corridor will be narrowed. Collateral conditions will be simplified both before and during the normalization.

About the foreign exchange liquidity measures, foreign exchange deposit limits will be increased before the normalization. The foreign exchange liquidity that the financial system will be able to access with the CBRT will be determined at the level that will more than meet the foreign payments of the next year of our banks. Both before and during the normalization, the flexibility of foreign exchange selling auctions will be increased in order to reduce the exchange rate fluctuation and foreign exchange liquidity in the financial system will be provided by raising the partial interest paid to Turkish lira reserve requirements or by arranging ROC. 
Lastly, about the measures that will support financial stability before normalization maturities of Non-Core Liabilities will be extended. Partial interest paid on Turkish lira required reserves may be revised in order to reduce the intermediation costs of the banking sector in the upcoming period and to support core liabilities and interest rates paid on US dollar denominated required reserves, reserve options and free accounts will be maintained at levels close to the upper bound of the Fed policy rate range both before and during the normalization.

Turkey case is a little differnet than Fed or ECB because of the magnitude of the overall economy. Additionally, interest rates never reached zero and inflation never stood under the target.

\section{Concluding Remarks}

The structural differences between Fed and ECB caused the reactions to financial crisis be different. Also both the normalization process and the effects may be distinctive. For instance type of bond purchases even create diversity among two central banks, Fed and ECB. Due to the close-ended bond purchases, ECB had to determine the duration of current programme. Tout court, structural and implementational differences among economies create different obstacles and opportunities and additionaly different results.

In the light of this variety, it is not so easy to define "What normal is?". Different conditions are even important to describe the conditions of being normal. Since it so much depends on time and space that will be compatible to read the normalization through the case of US economy.

Under 'normal' conditions it was expected the monetary easing would increase the inflation and interest rates. But after the global financial crisis, when the interest rates could not be used as a policy tool because of the zero lower bound the conventional mechanisms lost their functions. Quantitative easings of Fed could not increase neither interest rate nor inflation rate. Despite the low interest rates, growth rate still remains low. So, the case is far from normal. It is not very hard to say that there became a shift in the normality perception and the new facts became the 'new normal'. 
Under this new normal (or new Abnormal) Fed's balance sheet reduction is thought to cause liquidity shortage but since there is no certainity about the magnitude of the reduction, the effects of on global economy is still ambiguous through capital flows.

\section{REFERENCES}

Alper K., Kara, H. \& Yörükoğlu, M. (2013). Reserve Option Mechanism. Central Bank Review, Vol. 13, 1-14.

Ball, L., Gagnon, J., Honohan, P., \& Krogstrup, S. (2016). What Else Can Central Banks Do?. Geneva Reports on the World Economy 18, CEPR Press.

Bank of International Settlements BIS, 87th Annual Report.

Başç1, E. \& Kara, H. (2011). Financial Stability and Monetary Policy. CBRT Working Paper, No: $11 / 08$.

Beck G.W. \& Wieland, V. (2017). How to Normalize Monetary Policy in the Euro Area. Institute for Monetary and Financial Stability, Working Paper Series No.115.

Bindseil, U. (2016). Evaluating monetary policy operational frameworks, Paper presented at 2016 Economic Symposium organized by the Federal Reserve Bank of Kansas City, 24-26 August 2016, Jackson Hole, WY.

Blanchard, O \& Johnson, D. (2013) Macroeconomics, Pearson.

Carlos C., Carrière-Swallow, Y., Demir, I., \& Gruss, B. (2016). U.S. Monetary Policy Normalization and Global Interest Rates. IMF Working Paper WP/16/195.

Central Bank of Republic of Turkey, (2009). Annual Report.

Central Bank of Republic of Turkey, (2013). Annual Report.

Central Bank of Republic of Turkey, (2012). Annual Report.

Central Bank of Republic of Turkey, Bulletin 27

Central Bank of Republic of Turkey, Financial Stability Report May 2015

Cliffe, M. (2016). The New Normal That Never Was. Voxeu, http://voxeu.org/article/newnormal-never-was.

Cukierman, A. (2016). Global Crisis in the US vs the Eurozone: Banks and monetary policy. http://voxeu.org/article/global-crisis-us-vs-eurozone-banks-and-monetary-policy 
Fed (2014). Policy Normalization Principles and Plans. Fed statement available at https://www.federalreserve.gov/monetarypolicy/files/FOMC_PolicyNormalization.p df.

Greenwood, R., Hanson, S.G. \& Stein, J.C. (2016). The Federal Reserve's Balance Sheet as a FinancialStability Tool. Jackson Hole Economic Symposium Conference Proceedings, Jackson Hole, WY. (Federal Reserve Bank of Kansas City) 335-397.

Küçüksaraç, D. \& Özel, Ö. (2012). Reserve Options Mechanism and Computation of Reserve Options Coefficients. CBT Research Notes in Economics, Vol. 2012-33.

Perli, R. (2017). Normalizing Central Banks' Balance Sheets: What Is The New Normal?. Conference jointly organized by Columbia University's School of International and Public Affairs and the Federal Reserve Bank of New York.

Powell, J.H. (2017). Thoughts on the Normalization of Monetary Policy, Speech At the Economic Club of New York.

Robin Greenwood, R., Hanson, S.G. \& Stein, J.C. (2016). The Federal Reserve's Balance Sheet as a Financial-Stability Tool. Federal Reserve Bank of Kansas City’s 2016 Economic Policy Symposium in Jackson Hole.

Rosengren, E.S. (2016). Early Observations on Gradual Monetary Policy Normalization. The Greater Boston Chamber of Commerce Boston, Massachusetts.

Thomsen, P. (2017). The Euro Zone: What's Next. Financial Times Investment Management Summit, London, International Monetary Fund. 